Educational Research for Social Change (ERSC)

Volume 9 No. 1, June 2020

pp. 58-75

ersc.nmmu.ac.za

ISSN: 2221-4070

\title{
Connecting the Classroom to the Business World: Evolvement of a PALAR Journey in a Disciplinary Environment ${ }^{9}$
}

Salomien Boshoff

Akademia

Salomien@akademia.ac.za

\section{Naquita Fernandes}

University of the Free State

fernandesn@ufs.ac.za

\section{Abstract}

There is an increasing demand for skilled graduates who can integrate and apply theoretical knowledge in a real-world context. As a means of enhancing students' employability skills in an exit-level strategic marketing module, two lecturers embarked on a PALAR (participatory action learning action research) journey over a period of three years to design a skills-centred curriculum with corresponding assessments centred upon partnerships between educators, students, and businesses. In order to attain the desired level of practical learning, the partners formed part of the entire assessment process. This included the businesses' (local, national, and international) involvement in the process of identifying real-life problems that served as the foundation of the assessments. Furthermore, the business partners also formed part of the feedback system, empowering the students with practical, industry-specific feedback while, in turn, enhancing the businesses' idea generation process with insight obtained from the students' thinking. During this process, the lecturers redesigned assessments until strategic alignment was attained between the partners' needs and the module's exit-level outcomes. The results reveal that the partnerships between educators, students, and businesses added value to the students' learning experience and enhanced their perceived employability skills. This article thereby contributes to extant literature by explaining how the PALAR approach can be practically applied in the field of business management and marketing. The practical details provided can easily be utilised by educators in the same and other similar fields. Furthermore, an established set of reflective questions and a summary framework have been included, which can aid a lecturer in evolving a PALAR journey. This personal PALAR journey, and the reflection thereon, proved not to be rigid in nature but, instead, fluid and highly adaptable. Each recursive PALAR cycle (plan-act-evaluate/observe-reflect) is needed and cannot be completed without the others. In conclusion, the way one addresses each cycle will be unique to one's teaching style and discipline-specific needs. This article provides educators in similar positions with insight into how they can use a PALAR process when designing their modules and assessments to foster employable graduates.

\footnotetext{
${ }^{9}$ Ethical clearance number: UFS-HSD2016/1114/0305
} 
Keywords: higher education, teaching and learning, collaboration, business partnerships, PALAR, action research, employability

Copyright: (C) 2020 Boshoff \& Fernandes

This is an open access article distributed under the terms of the Creative Commons Attribution NonCommercial License, which permits unrestricted non-commercial use, distribution, and reproduction in any medium, provided the original author and source are credited.

Please reference as Boshoff, S. \& Fernandes, N. (2020). Connecting the Classroom to the Business World: Evolvement of a PALAR Journey in a Disciplinary Environment. Educational Research for Social Change, 9(0), 58-75. http://dx.doi.org/10.17159/2221-4070/2020/v9i0a5

\section{Introduction}

Employers expect graduates with business degrees to possess employability skills and competencies to apply their disciplinary knowledge in the workplace. As a result, university lecturers have a new responsibility to produce employable graduates who can contribute significantly to the world of work (Bernstein \& Osman, 2012). This led to the research question at hand: "What can be done, in terms of teaching and learning, to enhance students' employability skills and assist them to integrate theoretical knowledge in a realistic business-world setting?" Two lecturers of an exit-level B. Com Strategic Marketing module with more than 200 students aimed to create opportunities for applying marketing knowledge in a real-life setting through collaborative partnerships by following a PALAR (participatory action learning action research) process.

In this article, the two lecturers reflect on the way the module was designed (and redesigned) to forge a bridge between the classroom and the business world by utilising strategic business partnerships. The article reports on a journey of two lecturers who became researchers by indulging in an action learning $(A L)$ process and then gradually incorporating action research $(A R)$ as part of the evolvement of their particular (disciplinary) PALAR expedition. The article does not take the typical article format of research problem, methodology, and findings but is, rather, a reflection on a journey of change. The article commences with the theoretical underpinnings of the PALAR journey. It details the practical application of PALAR over a 3-year period. During this PALAR journey, various initiatives were undertaken to ensure that the needs of the three main stakeholders (educators, businesses, and students) were met through students' learning experiences. As the article progresses, the consequences of these teaching and learning initiatives are explained in terms of the impact they had on the three stakeholder groups. To conclude, the value of the PALAR approach for designing and teaching a module in the field of business management that aims to develop students' employability skills, is emphasised.

\section{A Theoretical Mapping of This PALAR Journey}

Partnerships can be defined as cooperative relationships with a shared goal, and where learning takes place within all stakeholders (Fletcher, 2015). Partnerships for teaching and learning are reported to yield benefits that result from engagement because the role-players tend to experience heightened motivation and learning (Felten et al., 2014). According to Green (2014), a student's learning and development is enhanced when business partners participate in the teaching and learning experience. Furthermore, the involvement of external role-players (such as business partners) enhances the learning environment, and reaps mutual benefits for all role-players involved (Green, 2014). In addition, business partnerships contribute to the collaborative nature of a PALAR process.

AL, a key element of PALAR, entails "learning from action or concrete experience" (Zuber-Skerritt, 2001 , p. 2). AR, the second part of PALAR, "aims to change practices, people's understandings of their 
practices and the conditions under which they practice" (Kemmis, 2009, p. 2). In this case, AL entailed a process by which groups of people (business partners, lecturers, and students) addressed actual workplace problems, taking into consideration complex real-life conditions (Zuber-Skerritt, 2002). Dick (2009) declared that AL is a powerful tool for improving the transfer of skills. As advised by Dick (2009), to improve employability skills, assignments should be real and relevant to the workplace. The need for businesses to participate in the development of authentic assessments (Griesel \& Parker, 2009) through AL served as impetus for this evolving PALAR journey, which was a collaborative-participatory paradigm grounded in AR. Kemmis et al. (2013) argued that the main aim of PALAR is to undertake critical research to change one's own educational practice (habitual or customary action) into praxis (informed and committed actions) that could lead to waves of change for all those involved.

The theory and praxis (the process by which a theory, lesson, or skill is enacted, embodied, or realised) of PALAR stem from aspects of existing theories, namely, grounded theory, action theory, critical education theory, systems theory, personal construct theory, and experiential learning theory (ZuberSkerritt, 2011). In order to contextualise this study within the existing body of knowledge, a short definition of each of these theories, together with an explanation of how each underlying theory influenced, guided, and supported this particular PALAR journey are presented in Table 1.

As is evident in Table 1, PALAR entails a collaborative critical reflection on one's work by several partners. Critical participatory action researchers engage in cycles of research within their own practice traditions by integrating theory, practice, research, and development (Zuber-Skerritt, 2016). This process is cumulative in nature and builds on previous cycles of planning by critically reflecting on partners' actions and experiences (Fletcher, 2015). The four recurring stages of PALAR (plan-actobserve/evaluate-reflect) result in a deeper understanding of one's changed practice and critical reflections. These cyclical stages assist researchers to collaboratively identify the needs of all participants. Based on the acknowledged needs, the best course of action is identified and implemented. Thereafter, the actions that were implemented are evaluated through a critical reflection by participants to decide which further actions should be taken, hence, showcasing the recursive nature of PALAR (Wood \& Zuber-Skerrit, 2013).

Kearney et al. identified the three R's of PALAR research that can be used as a guide when using this approach-relationship, reflection, and recognition-and these three components "promote a truly participatory approach to knowledge creation and practical social and educational improvements" (2013, p. 113). The three components were embedded in the foundation of this PALAR journey to trigger change in all participants' learning and knowledge.

In her description of PALAR, Zuber-Skerritt (2011) emphasised the importance of conceptualising the innovative processes that were followed, and of sharing the results of $A R$ in scholarly journals so that others can learn from it. This reporting should not only document the authors' professional development, but should, "legitimize PALAR in higher education, integrating theory with practice and research with teaching" (Zuber-Skerritt, 2011, p. 19). Consequently, the aim of this article is to reflect on a PALAR journey and the design (and redesign) of the activities and assessments to achieve the module's learning outcomes (including the development of employability skills) over a period of three years. With this objective in mind, the article presents a conceptualisation of the PALAR process that was followed to enhance students' employability skills by deliberately connecting the classroom with the business world. Through fostering partnerships between educators, students, and businesses, value was added to the students' learning experience and enhanced their perceived employability skills. During the PALAR journey, various initiatives were taken to ensure that the needs of the three main stakeholders (educators, businesses, and students) were met. In the section that follows, the practical application of the PALAR journey is discussed, including how each of the recurring stages was 
applied over a 3-year period in a strategic marketing module. And the results and findings provided by the participating stakeholders are addressed.

Table 1: How Theories Underpinning the Palar Praxis Guided the Study

\begin{tabular}{|c|c|c|}
\hline Theory & $\begin{array}{l}\text { Defined and explained by Zuber-Skerrit } \\
(2011, \text { p. 101) }\end{array}$ & $\begin{array}{l}\text { Guiding and supporting role of the theory } \\
\text { on the PALAR journey }\end{array}$ \\
\hline Grounded theory & $\begin{array}{l}\text { Solutions to problems, issues, and } \\
\text { challenging new questions are identified } \\
\text { from collected data, analysis of this data, } \\
\text { and interpretation based on participants' } \\
\text { practical life experience. }\end{array}$ & $\begin{array}{l}\text { Problems in the business world prompted } \\
\text { the lecturers to start the PALAR cycles of } \\
\text { plan-act-evaluate/observe-reflect. }\end{array}$ \\
\hline Action theory & $\begin{array}{l}\text { Participants themselves are the agents of } \\
\text { development and change who, through } \\
\text { trial and error as well as individual and } \\
\text { group reflection on and in action, come } \\
\text { to understand their social } \\
\text { situation/dilemmas. }\end{array}$ & $\begin{array}{l}\text { f Through trial and error over the 3-year } \\
\text { period, the researchers embarked on a } \\
\text { journey of critical individual and team (the } \\
\text { two lecturers') reflections, including critical } \\
\text { reflections by students and business } \\
\text { partners. }\end{array}$ \\
\hline $\begin{array}{l}\text { Critical education } \\
\text { theory }\end{array}$ & $\begin{array}{l}\text { Participants as equal partners in } \\
\text { "symmetrical communication" are free to } \\
\text { explore any way in which their situation } \\
\text { under consideration can be improved, } \\
\text { even if constraining conditions must be } \\
\text { removed or changed. }\end{array}$ & $\begin{array}{l}\text { Critical dialogues between all participants } \\
\text { led to improved assessments that are } \\
\text { authentic in nature and focused on } \\
\text { empowering students with skills. }\end{array}$ \\
\hline Systems theory & $\begin{array}{l}\text { Participants take a systemic, holistic } \\
\text { approach to inquiry and subsequent } \\
\text { improvement of praxis. }\end{array}$ & $\begin{array}{l}\text { The assessments were not analysed in } \\
\text { isolation, but with the holistic development } \\
\text { of students and the student voice as } \\
\text { drivers. }\end{array}$ \\
\hline $\begin{array}{l}\text { Personal construct } \\
\text { theory }\end{array}$ & $\begin{array}{l}\text { The researcher is not an unattached } \\
\text { outside observer, but a facilitator of } \\
\text { participants' construction of knowledge } \\
\text { and their interpretation of this } \\
\text { knowledge for their consequent } \\
\text { behaviour, attitudes, values, and } \\
\text { responsibilities in real-life situations. }\end{array}$ & $\begin{array}{l}\text { The PALAR journey began with the role of } \\
\text { lecturers, focused on improving our } \\
\text { students' employability skills. In addressing } \\
\text { the needs and problems, the role of } \\
\text { researchers was applied. }\end{array}$ \\
\hline $\begin{array}{l}\text { Experiential learning } \\
\text { theory }\end{array}$ & $\begin{array}{l}\text { Participants create knowledge and } \\
\text { insights based on concrete experience, } \\
\text { reflecting on this experience, and } \\
\text { identifying their learning from reflection. }\end{array}$ & $\begin{array}{l}\text { The reflection of each year aided in the } \\
\text { planning for the next year-showcasing the } \\
\text { cyclical nature of PALAR and reflection. }\end{array}$ \\
\hline
\end{tabular}

\section{The PALAR Journey}

The PALAR journey for the two lecturers began with a critical reflection session in which a research problem was identified, namely, students' lack of employability skills. The action steps taken to resolve the problem entailed collaborating with the business partners-engaging in critical reflection on their business practices and identifying problem areas. Assessments were then created, requiring students to develop strategies to address these problems through the practical application of their newly acquired marketing theory (see Table 2). The assessments aimed to assist businesses in addressing their respective problems and, in the process, develop students' employability skills. Through these initiatives, AL was stimulated. 
The cycles of plan-act-observe/evaluate-reflect pertaining to the 3-year PALAR journey will be discussed, showcasing how the researchers developed a deeper understanding of their own practice by critically reflecting on feedback from the stakeholders, namely, students and business representatives.

Table 2: Participating Companies and Assessment Formats Used in the Various Cycles

\begin{tabular}{|c|c|c|c|}
\hline Pseudonym & Explanation & Type of assessment/assignment & $\begin{array}{l}\text { Used during following } \\
\text { cycle }\end{array}$ \\
\hline INT001 & $\begin{array}{l}\text { International company with } \\
\text { several business units in } \\
\text { various industries. }\end{array}$ & $\begin{array}{l}\text { Summative assessment in the form of } \\
\text { a group-based oral presentation. }\end{array}$ & $\mathrm{Y} 1, \mathrm{Y} 2, \mathrm{Y} 3$ \\
\hline COURIER1 & $\begin{array}{l}\text { An international courier } \\
\text { company, of which the local } \\
\text { branch participated. }\end{array}$ & $\begin{array}{l}\text { Formative group assessment in the } \\
\text { form of a poster where news } \\
\text { happenings were identified that could } \\
\text { affect the business. Action plans were } \\
\text { to be developed to assist the business } \\
\text { in dealing with the external business } \\
\text { environment. }\end{array}$ & Only Y2 \\
\hline COFFY01 & $\begin{array}{l}\text { A local takeaway coffee and } \\
\text { frozen yogurt company on } \\
\text { campus. }\end{array}$ & $\begin{array}{l}\text { Formative group assessment orally } \\
\text { presented with a written document } \\
\text { designed around a market research- } \\
\text { related problem the business partner } \\
\text { experienced at that time. }\end{array}$ & Only Y2 \\
\hline LOCSL01 & $\begin{array}{l}\text { Local sport and leisure } \\
\text { business that trains children } \\
\text { and adults in a specific sport. }\end{array}$ & $\begin{array}{l}\text { Formative assessments based on } \\
\text { LOCSL01, LOCCPO2, LOCNP03, } \\
\text { LOCMC04: }\end{array}$ & Only Y3 \\
\hline LOCCPO2 & $\begin{array}{l}\text { Local courier and printing } \\
\text { company that is part of a } \\
\text { franchise group. }\end{array}$ & $\begin{array}{l}\text { Marketing research group-based oral } \\
\text { presentation related to a current, real- } \\
\text { life problem the business owner } \\
\text { experienced. }\end{array}$ & \\
\hline LOCNP03 & $\begin{array}{l}\text { Nonprofit organisation that } \\
\text { bridges the gap between } \\
\text { business and community. }\end{array}$ & $\begin{array}{l}\text { Identification of a market segment, } \\
\text { targeting strategy and positioning } \\
\text { approach that could be used by the } \\
\text { company. }\end{array}$ & \\
\hline \multirow[t]{2}{*}{ LOCMCO4 } & \multirow{2}{*}{$\begin{array}{l}\text { A local brick-and-click (online } \\
\text { business and physical store) } \\
\text { men's clothing company. }\end{array}$} & $\begin{array}{l}\text { Marketing mix written assignment as } \\
\text { individuals. }\end{array}$ & \\
\hline & & $\begin{array}{l}\text { Electronic media analysis as a group- } \\
\text { based written assignment. }\end{array}$ & \\
\hline
\end{tabular}

The methodology adopted in the AR varied per cycle, however, the student voice remained at the heart of all three cycles. Each cycle made use of a different set of students because once they completed the course, they progressed to the world of work. This strengthened the student voice and provided the lecturing team with a holistic view into ever-changing student needs (Seale, 2009). During the first and second cycles (Y1 and $\mathrm{Y} 2$ ), student feedback forms were used, which contained questions regarding the student experiences (Seale, 2009). Students critically reflected on their learning journey, assessments, and activities in the module. Insights derived from this feedback aided the lecturers to make necessary adjustments to the module and assessments going forward. During Year 3 , a survey containing both quantitative and qualitative elements was used to assess students' employability skills 
pre and post module completion. The population in each year was the registered students for the exitlevel strategic marketing module.

Across all cycles, the ethical values of action research were applied. This entailed obtaining ethical clearance (which was granted for the umbrella project: UFS-HSD2016/1114/0305). Furthermore, at the start of the semester, all module participants signed consent forms for their data to be used for publication purposes. Confidentiality and anonymity were assured for the business partners as well as the students by incorporating pseudonyms. In terms of data analysis, the student feedback was thematically analysed (Creswell \& Creswell, 2017) independently by the two lecturers who then came to a consensus. The pre- and post-test questionnaire data was analysed by means of inferential statistics using ANOVA and t-tests.

\section{Cycle 1 (Y1): The Year of Realisation}

\section{Plan Y1}

The collaboration started in Year 1 (Y1), when the two lecturers were assigned to the Strategic Marketing module. During the planning phase, the researchers critically reflected on past teaching experiences and prior student feedback. To kick-start the planning cycle, a unified vision was developed, based on bringing the business world into the classroom. This was done to improve students' employability skills. The researchers reflected on how to teach the discipline-specific content and, in the process, assist students to solve learning tasks associated with understanding concepts in the discipline. According to Ashwin et al. (2020, p. 46), "reflective teaching is sparked by dissatisfaction." In order to identify the factors of dissatisfaction, regular needs analyses were conducted via consultations with students as well as conversations with business partners.

The needs analysis showed that, firstly, the students themselves, who were responsible for their own learning, had a set of general needs and concerns including finding jobs, being skilled and ready for the workplace, and acquiring relevant work experience. In addition, students wanted to recognise the reallife value of the module. Secondly, the lecturers, who have the authority to design curricula and course content that can either improve or hinder students' employability skills development, also had needs. Lecturers' needs and wants were based on efficient and effective handling of large classes, simplifying the grading of assessments, finding a balance between explanation of course content and practical activities, and ensuring that students developed employability skills through their participation in the module. Additionally, lecturers were time constrained and had to balance their teaching roles, research responsibilities, community service initiatives, and life itself. Lastly, the needs of the business partners, as stakeholders who have the authority to hire or reject the students as potential workplace candidates, were focused on finding suitable workplace candidates who possessed practical skills, are task directed, and have the ability to apply their acquired knowledge. These needs are confirmed by the research conducted by Griesel and Parker (2009), who identified task-directed engagement and the application of knowledge as two salient concerns that South African employers have highlighted upon the recruitment of graduates.

\section{Act $Y 1$}

Assessments were developed with the overarching goal to empower students to be theory-based practitioners who solve real-life problems, thereby becoming more employable in their discipline. A summative assessment in the form of a group oral presentation was created in Year 1 in collaboration with an international company (INTO01) that comprises of multiple sub-companies in a wide range of business industries. The students were assigned to develop practical marketing strategies for any one of the INT001 companies operating in Africa. Students presented these ideas to a local panel of judges. The top 20 students were selected to present their ideas individually to representatives of the 
company and other external judges (from the private sector). The judges provided critical feedback to the students, as done in real-life business pitches. A formal function was organised to take place after the student presentations to showcase the students' accomplishments, addressing the third $R$ of PALAR - recognition. Attendees included students and their family and friends, business partners, lecturers, head of the Business Management department and the dean of the faculty. This function provided the perfect avenue for engagement because all role-players were brought together.

\section{Observe/Evaluate Y1}

During this stage of evaluation, in-class observations and after-class assessment reflections were conducted. Students' module evaluations and business representatives' feedback were also consulted, as reported below.

\section{Student Perspective}

Students appreciated the opportunity to work on the INT001 project (explained above) because they believed this assessment equipped them with necessary employability skills. The students' comments about the experience summarised how the business partnership heightened student learning and enjoyment thereof:

Participant 3 (Y1): By participating in the INT001 project, I felt like I was really learning how things will be in a work setting.

Participant 7 (Y1): I enjoyed the challenge of the INT001 assignment, as it helped us further put our skills in practice.

Students started to utilise theory to create practical solutions, thereby developing a deeper understanding of what can work in a practical sense and what cannot:

Participant 12 (Y1): It was nice to do an assignment on a real company that is growing. Learned how to use theory with practical.

Although positive feedback had been obtained, the students mentioned that they had, at times, felt challenged and overwhelmed due to the assessment requirements and the time constraints. Participants articulated these problem areas explicitly:

Participant 18 (Y1): Was tricky because had to come up with strategies. Out of comfort zone but good to be in an unknown situation.

Participant 15 (Y1): Too much to do, too little time.

\section{Business Perspective}

From a business perspective, the partnership was viewed as a tool of empowerment. INT001 saw their contribution as a driver of student growth, not only to achieve course success, but to inspire future possibilities, as articulated by the executive director of INT001:

INT001 Managing Director: We are very honoured to inspire young minds to come up with innovative marketing solutions to the INTO01 business. We hope that their creativity will also inspire innovations in business, government, and civil society that will ultimately sell better, South Africa and Africa as investment destinations. 


\section{Reflect $Y 1$}

Critical team reflection sessions were conducted weekly. Notes were made for the coming year on how to change practices. Resultantly, current practices and habitual actions were adapted. The biggest concerns were based on the time-consuming nature of arranging the INT001 presentations. These arrangements included setting up a presentation schedule, booking venues, communicating with business partners, and providing feedback to the students. The INT001 summative assessment was improved and adapted in accordance with stakeholders' suggestions and students' concerns. Consequently, the two lecturers' reflections helped them improve the INT001 presentation rubric to better guide the students. As a result, the initial assignment instructions, which were broad in the absence of a rubric, were improved to include specific guidelines and a suitable rubric that addressed all partners' needs. In addition, formative assessments were refined for Year 2 to help students integrate knowledge instead of confusing and frustrating students and, in the process, to develop better-prepared students.

\section{Cycle 2 (Y2): The Year of Adaptation}

\section{Plan Y2}

At the end of Year 1, the lecturers decided to adapt their vision in accordance with the experience they had gained. Inspired by Anderson et al.'s (2001) revision of Bloom's taxonomy (understand, apply, and analyse), an adapted vision was created with a 3-tiered teaching and learning philosophy: understand, think, and create. The lecturers aimed to create an understanding of difficult theoretical concepts by presenting examples in class. Secondly, the lecturers wanted to ensure that students think critically about the theoretical concepts-as noted by Griesel and Parker (2009) who emphasised the importance of application of knowledge in the workplace. Lastly, students were provided with an opportunity to create something new, such as feasible marketing strategies for existing businesses.

During the Year 1 reflection, newly developed needs on the students' side were identified, based on their lack of exposure to practical assignments. Consequently, two formative assessments in cooperation with two local businesses, COURIER1 and COFFY01 (refer to Table 2) were developed. The respective owners visited the class to present real-life business problems. The aim of these assignments was to enhance student understanding and provide students with the opportunity to put their newly acquired disciplinary knowledge into practice before completing their summative assignment on INT001.

During Year 2, a detailed resources inventory was conducted, which helped the lecturers identify the resources needed to attain project success. These resources included (a) people: open-minded people involved in local businesses, who are willing to share real-life problems and utilise student ideas to solve these problems. Additionally, a network of expert judges who could assist in assessing the summative assessment (INT001) was identified. These judges comprised of businessmen and women as well as academic colleagues. Financial resources (b) were also needed in order to cover the costs of the refreshments for the judges and the costs of hosting a prize-giving event for our summative assessment. Another resource (c) was the availability of venues and technological infrastructure such as projectors, internet connection, and microphones. Lastly, on a personal level, the lecturers realised that this process required a great deal of (d) time. The obstacles caused by resource limitations will be reflected on in a later section.

\section{Act $Y 2$}

During Year 2, formative practical assignments with detailed rubrics were developed to guide both students and judges. During two of these formative assessments, local businesses were involved and 
the following disciplinary topics were addressed: environmental scanning, segmentation, targeting and positioning process, market research, and the development of a four $\mathrm{P}$ (product, place, price, and promotional) strategy.

An example of the inner workings of one of the formative assessments was a marketing research project requiring students to identify a research problem from a presentation made by the business owner of COFFY01. In groups, students had to develop a research instrument, collect data, and present their findings to the business owners three weeks later. The lecturers and business owners scored the students' presentations according to a rubric. Business owners also provided valuable feedback on the practicality of the students' proposed strategies. Based on the feedback obtained from students and the business owners, this project was a success. The business owner immediately implemented some of the strategies proposed by the students.

\section{Observe/Evaluate Y2}

During Year 2, student feedback was obtained from formal end-of-semester student evaluations, continuous feedback forms, and in-class lecturer observations. Hoon et al. (2015) suggested that, if the purpose of student-generated feedback is to improve a module, the evaluation must include questions that explicitly ask what improvements can be made. Students had to answer the following three questions in relation to each of the assessments and activities completed during this module: (1) "What should we stop doing?" (2) "What can we improve?" and (3) "What should we keep on doing?" These evaluations were conducted twice during the semester: after the semester test (first summative assessment) and several formative assessments had been completed, and after the completion of INT001 (second summative assessment) and the remaining formative assessments. Feedback obtained is reported below.

\section{Student Perspective}

Regarding the INT001 assignment, the feedback that emerged was similar to that of Year 1, however, new insight was provided about the formative assessments involving the two local businesses. Students viewed the formative assessments as a tool to improve their understanding of theoretical content and to develop their practical application skills-maintaining their engagement throughout the learning process:

Participant 13 (Y2): The practical assignments and real business situations helped my learning-kept me engaged.

Students identified the following two potential problem areas: the number of assignments, and the time-consuming nature of the practical activities, as one student noted:

Participant 34 (Y2): The workload is too much, students have other modules too.

\section{Business Perspective}

The solutions developed by the students had considerable practical implementation value given that the COFFY01 business owner managed to implement the solutions and achieve success, as indicated in the comment:

COFFY01 Owner: We were able to gain valuable feedback in better understanding what our customers truly cared about. Some ideas that we have implemented since the presentations include some tweaks in pricing, displaying images of our products in-store, 
and hand writing personalised messages on our coffee cups, which have become popular on social media.

Although the overall feedback was positive, there were a few concerns regarding practicality brought up by the manager of the local COURIER1 branch:

COURIER1 Manager: It was a great opportunity for our brand to increase brand awareness. The students came up with some good ideas, but some of the ideas were a bit impractical and strategies far-fetched.

\section{Reflect Y2}

The reflection on the Year 2 action plan and newly implemented practical assignments led us to the realisation of the potential of participatory business-based assessments. Energised by the feedback from students and businesses, another set of practical assignments, in conjunction with local business partners, were designed and implemented in Cycle 3. However, with a class of approximately 200 students, three group presentations were too time-consuming for all the involved role-players. This led to new plans in Year 3.

\section{Cycle 3 (Y3): The Year of Focus}

\section{Plan Y3}

In a study that set out to determine the needed employability skills for graduates in the South African context, Coetzee (2014) developed an employability framework (refer to Figure 1). This framework outlines eight skill sets a South African graduate should possess in order to successfully transition to the world of work. The framework served as the basis of Year 3's planning phase because the lecturers aimed to develop these sets of skills in their student cohort.

\section{Act $Y 3$}

To develop the employability skills mentioned in Figure 1, a new set of assessments were planned, taking into consideration the time-consuming nature of student presentations and the fact that students failed to grasp the holistic nature of the module and the assessments. Based on these two constraints, partnerships with four local companies (LOCSL01, LOCCP02, LOCNP03, and LOCMCO4) were formed. Short videos were created in collaboration with the business partners, showcasing a summary of their real-life business challenges. These videos were then distributed to the students through the learning management system. In self-allocated groups, students had the option to choose between the four different local companies. A set of practical formative group assessments were developed, based on the video content. Each assessment that formed part of this set covered an element of a marketing plan. This was a strategy used by the lecturers to assist students to understand what each element entails and, also, to foster holistic thinking because each element needs to strategically integrate with the others in order for a feasible marketing plan to be developed. To ensure that the students still received critical feedback, one student presentation to the business owners formed part of the assessment strategy. 
Figure 1. Definitions of Employability Skills (Coetzee, 2014, pp. 893-896)

\begin{tabular}{ll} 
Interaction skills & $\begin{array}{l}\text { Using the English language and technology when communicating with others. } \\
\text { Personal efficacy in communicating and interacting with people from diverse } \\
\text { cultures, backgrounds, and authority levels. }\end{array}$ \\
\hline Enterprising & $\begin{array}{l}\text { Venturesome application of critical reasoning, initiative, and proactivity in } \\
\text { engagement of economic activities or undertakings. }\end{array}$ \\
\hline $\begin{array}{l}\text { Problem solving and } \\
\text { decision making }\end{array}$ & $\begin{array}{l}\text { Creativity and proactivity in the process of producing a solution to a recognised } \\
\text { problem or problematic situation. }\end{array}$ \\
\hline $\begin{array}{l}\text { Presenting and } \\
\text { applying } \\
\text { information skills }\end{array}$ & $\begin{array}{l}\text { Communicating knowledge, facts, ideas, and opinions clearly and convincingly with a } \\
\text { view to offering solutions for one's personal benefit, or for the benefit of one's } \\
\text { community or workplace. }\end{array}$
\end{tabular}

\begin{tabular}{ll}
\hline $\begin{array}{l}\text { Continuous learning } \\
\text { orientation }\end{array}$ & $\begin{array}{l}\text { Cognitive openness towards and awareness of, and proactive engagement in, the } \\
\text { process of acquiring new knowledge, skills, and abilities throughout one's life and } \\
\text { career in reaction to, and in anticipation of, changing technology and performance } \\
\text { criteria. }\end{array}$
\end{tabular}

Goal-directed
$\begin{aligned} & \text { Proactivity and initiative in achieving one's goals, accomplishing tasks, or meeting } \\ & \text { deadlines. }\end{aligned}$

\begin{tabular}{ll}
\hline $\begin{array}{l}\text { Ethical and } \\
\text { responsible } \\
\text { behaviour }\end{array}$ & $\begin{array}{l}\text { Responsible leadership in upholding the code of moral beliefs and values of one's } \\
\text { profession, community, and/or workplace in all one does. }\end{array}$ \\
\hline $\begin{array}{l}\text { Analytical thinking } \\
\text { skills }\end{array}$ & $\begin{array}{l}\text { Skilful, logical, and critical reasoning and analysis in explaining information and data } \\
\text { and drawing insightful conclusions from the data analysis. }\end{array}$ \\
\hline
\end{tabular}

\section{Observe Y3}

The two lecturers' observations in Year 3 incorporated quantitative research in the form of a pre- and post-test questionnaire based on Coetzee's (2014) work, which measured students' perceptions of their employability skills before and after they had completed the course. This AL journey was gradually changing into a strong AR and scholarly journey.

To establish the students' perceived employability skills, a pre-test with statements drawn from Coetzee's (2014) work was developed. These statements were rated on a 5-point Likert scale. Additionally, two open-ended questions were added: (1) "What, during the past six months, contributed to the development of the abovementioned skill?" and (2) "If the strategic marketing module was a positive contributor, which aspects of the module led to the improvement of this skill?" The key qualitative findings from the second open-ended question provided a synopsis of the views of the student cohort.

Of the initial sample of 214 registered students in Year 3, 152 completed the pre-test. Just over half the sample (51\%) were aged between 21 and 23 years, while $19.9 \%$ were younger than 21 . Only $1 \%$ was older. One third of the students were males, whilst $67.8 \%$ were females. In response to the question, "Do you set personal goals?" 97\% indicated that they did indeed. Job advertisements were 
reviewed by $40 \%$ of the students, an activity that is encouraged to prepare a student for the world of work.

Three months after completing the module, 136 of 214 registered students completed the post-test questionnaire, designed on the same basis as the pre-test. As part of the ethical considerations and to ensure anonymity, but to be able to link the pre and post tests, pseudonyms were used. The data was analysed using SPSS and the results pertaining to the research question at hand are discussed below.

\section{Quantitative Results}

To test the reliability, the Cronbach's Alpha measurement was used. Pallant (2013) considered a value greater than 0.7 to be reliable. Five of the eight skills will therefore be included in the analyses (Table 3): interactive skills, continuous learning orientation, goal-directed behaviours, ethical and responsible behaviour, and analytical thinking skills.

Regarding the mean scores, it is evident that a positive difference (ranging from +0.08 to +0.18 ) occurred in the students' perceived interactive skills (IS), continuous learning orientation (CL), goaldirected behaviour (GS), ethical and responsible behaviour (E), and analytical thinking skills (AS). In order to deter whether this positive difference could be attributed to the module's teaching and learning pedagogy, further qualitative results were analysed.

Table 3: Cronbach Alpha and Mean Scores of Pre- and Post-tests

\begin{tabular}{|c|c|c|c|c|c|}
\hline \multirow{2}{*}{$\begin{array}{l}\text { Cronbach Alpha of Pre- and Post- } \\
\text { tests } \\
\text { Employability skills as identified by } \\
\text { Coetzee (2014) }\end{array}$} & \multicolumn{2}{|c|}{ Cronbach Alpha } & \multirow{2}{*}{$\begin{array}{l}\text { Mean } \\
\text { Pre-test }\end{array}$} & \multirow[b]{2}{*}{ Post-test } & \multirow[b]{2}{*}{ Difference } \\
\hline & Pre-test & Post-test & & & \\
\hline Interactive Skills (IS) & 0.818 & 0.839 & 3.94 & 4.13 & 0.18 \\
\hline Enterprising (ES) & 0.678 & 0.661 & 3.76 & 3.87 & 0.10 \\
\hline $\begin{array}{l}\text { Problem-solving and decision-making } \\
\text { skills (PS) }\end{array}$ & 0.690 & 0.761 & 3.81 & 3.92 & 0.11 \\
\hline $\begin{array}{l}\text { Presenting and applying information } \\
\text { skills (PA) }\end{array}$ & 0.595 & 0.628 & 3.83 & 4.00 & 0.16 \\
\hline Continuous learning orientation $(\mathrm{CL})$ & 0.745 & 0.790 & 3.83 & 4.00 & 0.16 \\
\hline Goal-directed behaviour (GS) & 0.756 & 0.795 & 3.86 & 3.98 & 0.12 \\
\hline Ethical and responsible behaviour (E) & 0.733 & 0.770 & 4.18 & 4.26 & 0.08 \\
\hline Analytical thinking skills (AS) & 0.863 & 0.888 & 3.68 & 3.79 & 0.11 \\
\hline
\end{tabular}

\section{Qualitative Results}

The students classified the INT001 group project and the presentations to the business owners as the two major contributors to the development of their interaction skills as specifically mentioned by 112 of the 214 participants:

Participant 13 (Y3): The INTOO1 assignments helped me acquire skills and knowledge in communicating and interacting with large organisations. 
Participant 51 (Y3): All the assignments, because we worked with real companies and clients.

The enterprising skill (defined in Figure 1) was enhanced through the lecturers' teaching styles, which challenged students to use their acquired knowledge and apply it to their everyday lives. Half the student cohort mentioned INT001 and the other practical assignments as positive influencers in this regard:

Participant 18 (Y3): Lecturers in class and real-life examples and assessments.

Participant 85 (Y3): We were challenged to always think further-out-of-the-box ideas, especially with the INTO01 assignment.

Most students mentioned that the authentic, practical assignments developed their problem-solving skills:

Participant 91 (Y3): The INTO01 assignment helped us realise the urgency of future planning.

Participant 65 (Y3): By solving problems for clients and thinking of ideas in assignments.

The presentations, based on the research project and the INT001 project, were the main contributors to students' presentation and application of information skills:

Participant 125 (Y3): The practicality of the presentations in the modules and my lecturer were very helpful.

Students perceived an improvement in their continuous learning orientation due to the authentic nature of the assignments and teaching style:

Participant 206 (Y3): Attending classes and the way lecturers prepare and interact with us.

Participants 64 and 77 (Y3): Doing assignments of different kinds on the same company.

The strongest determinants of the students' goal-directed skills were the module's workload as well as the assessments developed in collaboration with the business partners:

Participant 8 (Y3): The presentations had deadlines that we had to meet.

Participant 85 (Y3): All the assignments that we had to hand in.

The group projects were recorded as an important factor that contributed to the advancement of ethical and responsible behaviours:

Participant 12 (Y3): Having to deal with people when doing assignments.

Participant 124 (Y3): Working in groups taught me how to take others in account.

Analytical thinking skills were developed through the formative-based research project as well as the INT001 assessment: 
Participant 158 (Y3): While it was difficult, to do research and analyses the data to make decisions for a business.

Participant 66 (Y3): Developing questionnaires as a source that was used in statistical analyses, and INTOO1.

Based on the reported feedback, it became evident that the assessments (INT001 and set of practical assignments relating to local businesses) improved the students' perceived employability skills. From the businesses' point of view, the collaborations provided the business representatives with novel perspectives that led to new strategies, which were applied in their businesses, as emphasised by the business owner of LOCSL01:

LOCSL01 Owner: The research your students performed and the feedback I obtained helped me so much in achieving my goal in creating a better and simpler website for my business. The data that I got made my decision-making process a lot simpler and guided me in the direction I need to go.

Despite general positive dispositions, the issue of student under preparedness was brought forward, specifically in terms of their ability to practically handle real-life business problems:

LOCCPO2 Owner: The strategies proposed by students were not always viable due to red tape within the company.

\section{Reflect $Y 3$}

Due to the diverse nature of the four companies, it was easier to apply the disciplinary principles to some more than to others. Based on the discrepancies, it was decided that, in future, the companies should have similar products or services. This becomes increasingly important with the formative assignments where the focus should be on learning how to apply theoretical concepts.

Based on the evidence, the stakeholders' practices and perspectives evolved for the better. Lecturers practised better teaching principles with the student voice as their foundation, students' employability skills were improved, and business partners acquired fresh business ideas. Table 4 indicates how the students' success rate drastically increased, from $64 \%$ (in the two years prior to the establishment of this team of lecturers) to $92 \%$ in Year 3. From Year $2(79 \%)$ to Year $3(92 \%)$ a significant increase in success rate was reported.

Table 4: Student Results Over a 5-Year Period

\begin{tabular}{lccccc}
\hline & $\begin{array}{l}\text { YA: Before } \\
\text { team had } \\
\text { been } \\
\text { established }\end{array}$ & $\begin{array}{l}\text { YB: Before } \\
\text { team had } \\
\text { been } \\
\text { established }\end{array}$ & $\begin{array}{l}\text { Y1: After } \\
\text { team had } \\
\text { been } \\
\text { established }\end{array}$ & $\begin{array}{l}\text { Y2: After } \\
\text { incorporation } \\
\text { of two } \\
\text { business } \\
\text { partners }\end{array}$ & $\begin{array}{l}\text { Y3: After } \\
\text { incorporation of } \\
\text { business partners } \\
\text { in all formative } \\
\text { assignments }\end{array}$ \\
\hline Average semester mark & $52 \%$ & $55 \%$ & $54 \%$ & $55 \%$ & $58 \%$ \\
Average exam mark & $49.5 \%$ & $50.5 \%$ & $54.5 \%$ & $50.5 \%$ & $58 \%$ \\
Average final mark & $54 \%$ & $56 \%$ & $58 \%$ & $56 \%$ & $60 \%$ \\
\hline Success rate & $64 \%$ & $78 \%$ & $77 \%$ & $79 \%$ & $92 \%$ \\
\hline
\end{tabular}


The findings in Table 3 and 4, in conjunction with the qualitative results, provide evidence of the realisation of the lecturers' vision and accompanying goal-to develop more employable graduates.

\section{Theoretical and Practical Contributions}

This paper contributes to the body of knowledge by showcasing how the PALAR approach can be applied practically in the fields of business management and marketing.

The details provided of the approach can easily be utilised by educators in the same and other similar fields. As a practical contribution, a set of reflective questions that could help lecturers to evolve on a PALAR journey was established. Table 5 lists the questions and examples of answers to these questions, which can serve as a guideline.

Table 5: Reflective Questions To Address When Developing a PALAR Project (Authors' Own)

\begin{tabular}{ll}
\hline Questions & $\begin{array}{l}\text { Examples of the two lecturers' answers } \\
\text { to these questions }\end{array}$
\end{tabular}

What is your teaching and learning philosophy? (Self-reflective statement summarising beliefs about teaching and learning.)

Who are the important stakeholders in your module?

What are the current problems/needs they experience?

What do I need to do to help stakeholders overcome these problems/needs?

At the end of the semester, what type of student would I like to send out of my class?

How can I involve real-life problems in my course by collaborating with businesses or discipline-specific outside partners?

How can I collect evidence of my teaching and learning practices to ensure that, in a year or two, I can share this knowledge with my peers?

What can I do to improve my teaching and learning practices, to develop all stakeholder skills or satisfy their problems/needs?
Produce a more employable student for the workplace.

Students

Lecturers

Business partners

Students: Employability skills

Lecturers: Teaching and reflection skills as well as research skills

Businesses: Employable students and solutions for their current problems.

Practical assignments with business involvement.

Students who can understand, think, create.

Identify areas in the disciplinary field that students and businesses struggle with.

Student feedback-mid-term, end of year

Lecturer critical reflections-informal notes

Business feedback-emails, letters, and interviews

Focus on more specific, real-life business problems. 
The PALAR process is not rigid in nature but, instead, fluid and highly adaptable. Figure 2 provides a summary of the evolving PALAR process. Each PALAR cycle (plan-act-evaluate/observe-reflect) is needed and cannot be completed without the other. These recursive cycles are flexible in nature. The way each cycle is addressed will be unique to the respective teaching style and discipline-specific needs, but the key element during these cycles is critical reflection throughout. Reflecting on one's teaching does not involve a set of strict rules but is a journey to utilise new understanding to enhance one's own practices.

Figure 2: Evolvement of the PALAR Journey in a Disciplinary Environment

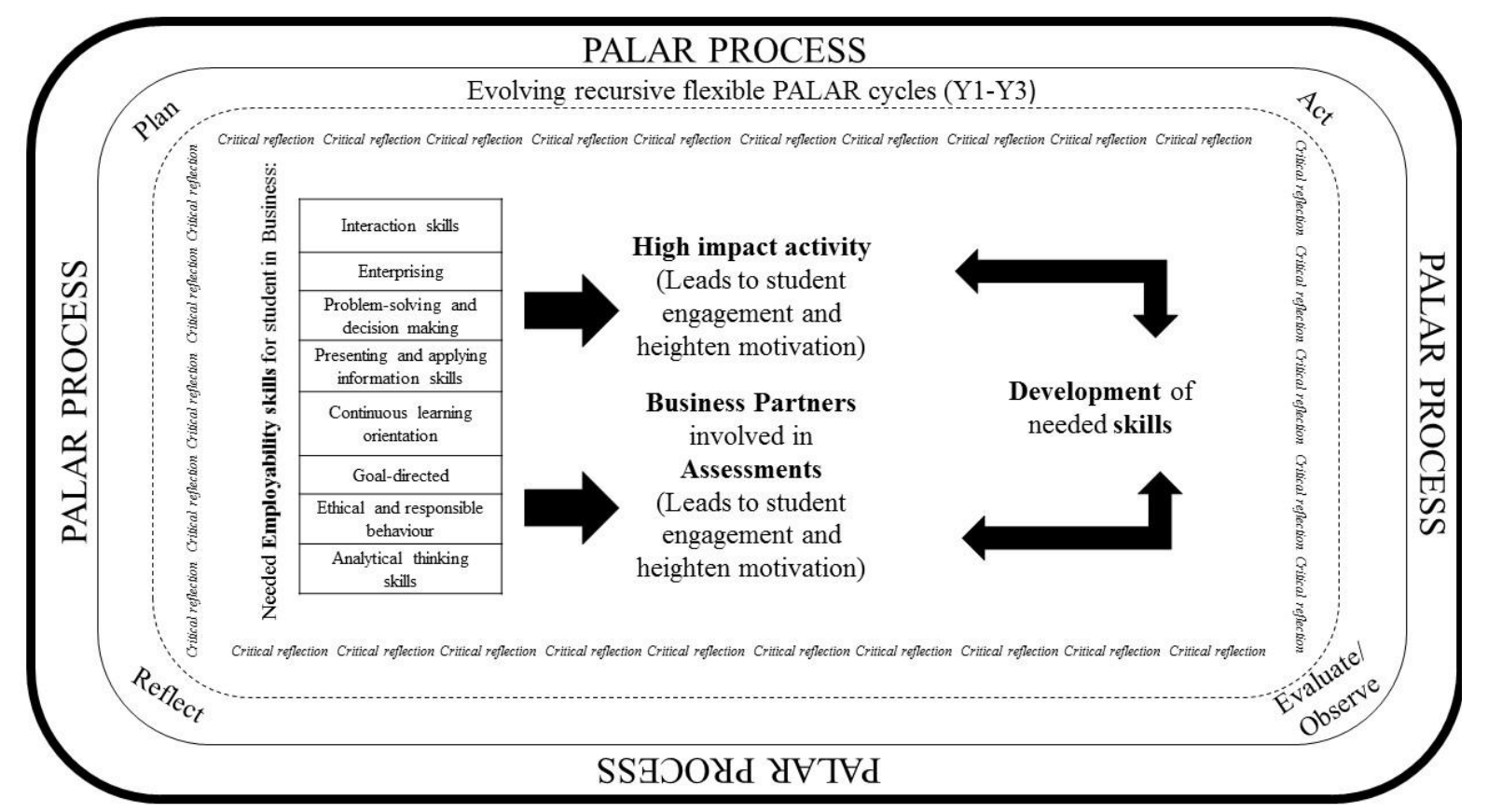

Results obtained from student feedback from Year 1 to Year 3 made it evident that assessment activities that incorporate business partners enhanced the students' perceived employability skills and assisted students to integrate theoretical knowledge in a realistic business world setting. AL took place in three ways: (1) The students gained disciplinary content knowledge from interaction with the lecturers and practical insight through the involvement of the business representatives, (2) the lecturers gained disciplinary knowledge and experience from the students and business feedback, and (3) the business representatives gained disciplinary insight from the students' ideas.

\section{Remaining Challenges}

Despite innovative solutions and a focus on collaboration, there were several unresolved challenges. In the future, Huang's (2010) and Moore's (2004) ideas, namely, that AR should move to a place where the students see themselves as participants in their own AL, should be incorporated. Gibbs et al. (2017) referred to a limitation of PALAR studies and publications - they are done predominantly by university academics (lecturers) and rarely involve the other stakeholders such as students or business partners. Our aim is to conduct a follow-up study with the business partners to review their PALAR journeys during involvement in this project. The business partners and students were part of the AL, although they did not participate in the analysis of the data. Future research projects will be incorporated to enhance the involvement of these partners in all four cycles of PALAR. This may address the criticism by Kemmis (2006) and Levin (2012) that a PALAR process prevents researchers from maintaining a critical distance from their own research, limiting transparent reasoning and the development of new insights. 


\section{Conclusion}

Student employability skills can be enhanced through collaborative business-based assessments. The reflection process of a PALAR philosophy, methodology, theory of learning, and facilitation process encouraged engagement with all stakeholders and potentially transformed the lecturers' practices.

In conclusion, this evolving PALAR journey has empowered the lecturers to break down the classroom walls that traditionally hindered holistic thinking. Instead, through partnerships and collaboration, bridges were built between the classroom and the real world. This approach has created a dynamic synergy that encourages students to learn from business mentors. In turn, businesses can access new ideas, recruit potential candidates, and create change far greater than they had imagined. By using PALAR, a process that enforces a positive social change for a just and better world for all the stakeholders involved, the researchers are committed to building bridges that nurture collaboration and develop students into employable graduates.

\section{References}

Anderson, L. W., D. R., Krathwohl, D. R., \& Bloom, B. S. (2001). A taxonomy for learning, teaching, and assessing: A revision of Bloom's taxonomy of educational objectives. Allyn \& Bacon.

Ashwin, P., Boud, D., Calkins, S., Coate, K., Hallett, F., Light, G., Luckett, K., McArthur, J., MacLaren, I., McLean, M., \& McCune, V. (2020). Reflective teaching in higher education. Bloomsbury.

Bernstein, C., \& Osman, R. (2012). Graduateness as a contested idea: Navigating expectations between higher education, employers and graduates. In M. Coetzee, J. Botha, N. Eccles, H. Nienaber, \& N. Holtzhausen (Eds.), Developing student graduateness and employability: Issues, provocations, theory and practical guidelines (pp. 45-64). KR Publishing.

Coetzee, M. (2014). Measuring student graduateness: Reliability and construct validity of the Graduate Skills and Attributes Scale. Higher Education Research \& Development, 33(5), 887-902.

Creswell, J. W., \& Creswell, J. D. (2017). Research design: Qualitative, quantitative, and mixed methods approaches. SAGE.

Dick, B. (2009). Action learning: Getting project teams to work.

http://www.babelfishgroup.com/files/ActionLearningSets.pdf

Felten, P., Bovill, C., \& Cook-Sather, A. (2014, June 16). Engaging students as partners in learning and teaching: Benefits and challenges-what do we know? [paper presentation]. ICED Conference, Stockholm. http://iced2014.se/proceedings/1194 Felten.pdf

Fletcher, M. (2015). Professional learning. In O. Zuber-Skerrit, M. A. Fletcher, \& J. Kearney (Eds.), Professional learning in higher education and communities (pp. 41-75). Palgrave Macmillan.

Gibbs, P., Cartney, P., Wilkinson, K., Parkinson, J., Cunningham, S., James-Reynolds, C., Zoubir, T., Brown, V., Barter, P., Sumner, P. and MacDonald, A. (2017). Literature review on the use of action research in higher education. Educational Action Research, 25(1), 3-22.

Green, R. (2014, July 2). Help students to be creative in class. Institution of Mechanical Engineers. https://www.imeche.org/news/news-article/help-students-to-be-creative-in-class

Griesel, H., \& Parker, B. (2009). Graduate attributes: A baseline study on South African graduates from the perspective of employers. Higher Education South Africa.

Hoon, A., Oliver, E., Szpakowska, K., \& Newton, P. (2015). Use of the 'Stop, Start, Continue' method is associated with the production of constructive qualitative feedback by students in higher education. Assessment \& Evaluation in Higher Education, 40(5), 755-767. 
Huang, H. B. (2010). What is good action research? Why the resurgent interest? Action Research, 8(1), 93-109.

Kearney, J., Wood, L., \& Zuber-Skerritt, O. (2013). Community-university partnerships: Using participatory action learning and action research (PALAR). International Journal of Community Research and Engagement, 6, 113-30.

Kemmis, S. (2006). Participatory action research and the public sphere. Educational Action Research, 14(4), 459-476.

Kemmis, S. (2009). Action research as a practice-based practice. Educational Action Research, 17(3), 463-474.

Kemmis, S., McTaggart, R., \& Nixon, R. (2013). Introducing critical participatory action research. In S. Kemmis, R. McTaggart, \& R. Nixon (Eds.), The action research planner: Doing critical participatory action research (pp. 1-31). Springer.

Levin, M. (2012). Academic integrity in action research. Action Research, 10(2), 133-149.

Moore, J. (2004). Living in the basement of the ivory tower: A graduate student's perspective of participatory action research within academic institutions. Educational Action Research, 12(1), 145-162.

Pallant, J. (2013). SPSS survival manual. McGraw-Hill.

Seale, J. (2009). Doing student voice work in higher education: An exploration of the value of participatory methods. British Educational Research Journal, 36(6), 995-1015.

Wood, L., \& Zuber-Skerrit, O. (2013). PALAR as a methodology for community engagement by faculties of education. South African Journal of Education, 33(4), 1-15.

Zuber-Skerritt, O. (2001). Action learning and action research: Paradigm, praxis and programs. In S. Sankara, B. Dick, \& R. Passfield (Eds.), Effective change management through action research and action learning: Concepts, perspectives, processes and applications (pp. 1- 20. Southern Cross University Press.

Zuber-Skerritt, O. (2002). A model for designing action learning and action research programs. The Learning Organization, 9(4), 143-149.

Zuber-Skerritt, O. (2011). Action leadership: Towards a participatory paradigm (Vol. 6). Springer.

Zuber-Skerritt, O. (2016). The action research planner: Doing critical participatory action research. Educational Action Research, 24(1), 150-154. 